\title{
Rapid assessment of the knowledge about Coleoptera (Arthropoda: Insecta) of forensic importance in an urban fragment of the Atlantic Forest in Salvador, Bahia, Brazil
}

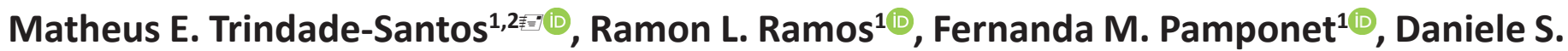 \\ Lopes $^{1 \oplus}$, Favízia F. Oliveira ${ }^{1 \oplus}$
}

${ }^{1}$ Universidade Federal da Bahia, Instituto de Biologia, Laboratório de Bionomia, Biogeografia e Sistemática de Insetos (BIOSIS), Bahia, Brazil. ${ }^{2}$ Universidade Estadual de Feira de Santana, Núcleo de Estudos em Agroecologia - Trilhas, Bahia, Brazil.

拝=-Corresponding author: mthtrindade@yahoo.com.br

Edited by: Alberto M. Silva-Neto

Received: March 14, 2021. Accepted: June 04, 2021. Published: June 28, 2021.

Abstract. Forensic Entomology can be defined as an area of Biological Sciences that uses the knowledge about insects and other Arthropods in criminal investigations, since decomposing corpses are sources of resources for arthropods, including insects belonging to the Coleoptera order. The objective of this work was to carry out a rapid assessment inventory of beetles of forensic importance in an urban fragment of the Atlantic Forest (Parque Metropolitano de Pituaçu) located in the city of Salvador, State of Bahia, Brazil. We conducted a collection in the dry period (January 2013) and another collection in the rainy period (July 2013). The capture of coleopterans took place through the use of "Pitfall" traps, stocked with a mixed bait (chicken gizzard and sardines). A total of 239 were collected, distributed in three families: Scarabaeidae (96.1\%), Staphylinidae (3.0\%) and Histeridae (0.9\%). The morphospecies Dicothomius sp. 1 (Scarabaeidae), was more abundant with $94.1 \%$ of the specimens sampled. The dry period was more representative for both richness and abundance. All species/morphospecies sampled already have previous records as belonging to forensic importance according to previous studies.

Keywords: Beetle, Faunal Inventory, Entomology, Pitfall traps.

Forensic Entomology can be defined as the area of Biological Sciences that uses knowledge about insects and other Arthropoda in legal matters, with the medico-legal aspect as the main one, in which knowledge about the biology and taxonomy of insects is employed in criminal investigations, especially those related to violent deaths (Lord \& Stevenson 1986; Ramos et al. 2018). In this context, the presence of both immature and adult insects colonizing corpses is used as an essential tool for calculating the "Post-Mortem" interval (PMI) estimate (Pujol-Luz et al. 2008; Ramos et al. 2018).

Decomposing bodies serve as a source of resources for several groups of organisms. Insects, which are pioneers in locating the body, use this new "micro-habitat" in various ways as copulation and/or reproduction sites, as well as a source of food and hiding (Catts \& Goff 1992; Lopes et al. 2018; Pamponet et al. 2019). In this sense, animals that visit carcasses are valuable tools for different studies in forensic sciences (Oliveira-Costa 2007; Mise et al. 2007; Ramos et al. 2018; Lopes et al. 2018; Pamponet et al. 2019).

Among insects of forensic interest, those of the order Coleoptera have attracted remarkable interest (Amendt et al. 2004), as their presence has been noted in carcasses in the final stages (fermentation and skeletonization) of the decomposition process (Mise et al. 2007; Fonseca et al. 2020). Thus, their presence, both as immatures and adults, in cadavers in advanced stages of decomposition is an important evidence from the medico-legal point of view, as it is essential for the determination of PMI of a corpse on advanced state of decomposition (Kulshrestha \& Satpathy 2001).

In terms of behavior regarding the colonization of decomposing bodies, Coleoptera has been considered the order of second importance among insects that act on cadaveric decomposition. According to Mise et al. (2007), the families Staphylinidae, Silphidae, Histeridae, Cleridae, Dermestidae, Scarabaeidae and Hydrophilidae are the main families that act in the decomposition process. These insects have a wide variety of eating habits, where some species can act as scavengers and others as predators and/or even as omnivores (Mise et al. 2007; Oliveira-Costa 2007). One example is Oxelytrum discicolle (Brullé, 1840) [Silphidae], where the immature is a scavenger and the adult a predator (Mise et al. 2007).

Brazil is the country with the greatest diversity of insects (Rafael et al. 2012), having about 84,775 described species (Oliveira et al. 2021), accounting for approximately $9 \%$ of the total fauna of this group on the planet. Today, this number is much higher due to the constant publications of new species of insects. From the point of view, entomofaunistic inventories are highly relevant for the knowledge of insect fauna in a given area, in addition to serving as a basis for several other studies. Likewise, in Forensic Entomology, local studies are essential to be applied, since each environment has its particularities, such as temperature, humidity, soil type, so increasing the knowledge about the species that act in cadaverous decomposition in the different regions of Brazil and that can be used as tools in this aspect (OliveiraCosta 2007; Ramos et al. 2018).

Rapid assessment studies, or rapid access to knowledge (Rapid Assessment), is a form of data collection carried out over a relatively short period of time, highly specific for a certain topic, as an opportunity to collect accurate information without the need for a more systematic project (Lima et al. 2016; Mishra et al. 2017). These studies can be used efficiently to obtain, complement, or analyze existing data to answer some specific questions. In this sense, our objective was to carry out a quick assessment of coleoptera of forensic importance residing in an urban fragment of the Atlantic Forest in the city of Salvador, Bahia, in the Northeast of Brazil.

The experiment was carried out in the Parque Metropolitano de Pituaçu $\left(12^{\circ} 56^{\prime} \mathrm{S}\right.$ and $\left.38^{\circ} 24^{\prime} \mathrm{W}\right)$, located in the city of Salvador, Bahia, 
Brazil. Currently, this park is the largest Conservation Unit in the city, with about 392 ha of Atlantic Forest (Bahia 2013) in different stages of regeneration. Although it is a conservation unit, the park has been suffering intense anthropic action.

Two sampling campaigns were carried out, one in the dry period (January 2013) and another one in the rainy period (July 2013). In total, 20 sampling points (PA) were determined equidistant in $50 \mathrm{~m}$, along the $15 \mathrm{~km}$ that surround the lagoon of Parque Metropolitano de Pituaçu. Each PA received a "Pitfall" type fall trap equipped with fresh mixed bait (chicken gizzards and sardines). The traps remained exposed for 72 hours, with the baits exchanged at 24-hour intervals and the insects collected. To verify the environmental variables, an environmental thermometer and a thermohygrometer were placed in each AP to measure temperature (maximum and minimum) and air humidity, respectively, during the exposure period of the traps.

The captured specimens were stored in $70 \%$ alcohol for conservation. All samples were sent to the Bionomy, Biogeography and Systematics Laboratory (BIOSIS) at the Federal University of Bahia (UFBA), where they were screened and the Coleoptera mounted on entomological pins and dried in an oven at $48^{\circ} \mathrm{C}$ for about 120 hours (equivalent to 5 days). The specimens were identified using the taxonomic keys present in Borror \& Delong (2010) for the family level in Silva et al. (2011) and Almeida \& Mise (2009) for genera and, species. After identification, the specimens were deposited at the Museum of Natural History of Bahia (MHNBA). The data generated were tabulated in a spreadsheet and analyzed using the Instat 3.0 software, where they were subjected to ANOVA to evaluate which of the two periods studied was the most abundant and which presented the most richness of individuals.

During the experiment, 239 individuals were sampled, distributed in 3 families and 6 species/morphospecies. The family Scarabaeidae was the most abundant $(96.1 \%)$ followed by Staphylinidae $(3.0 \%)$ and Histeridae (0.9\%) (Tab. 1). Among the representatives of Staphylinidae, we highlight Eulissus sp. 1 (Fig. 1B), which was collected only in the rainy season and which presented a $1.2 \%$ relative frequency. In the same period, Aleochara sp. 1 (Fig. 1C) (0.9\%) was also abundant (Table 1). In the dry period, Xanthopygus bicolor Laporte, 1835 (Fig. 1A) was the only representative of this family, with a frequency of $0.9 \%$ (Table 1). In Scarabaeidae, Dichotomius sp. 1 (Fig. 1E) was the most abundant morphospecies, representing $94.1 \%$ of the individuals collected, followed by Ontherus sp. 1 (Fig. 1D) with $2.0 \%$, both present in the two sampled periods (Tab. 1). In Histeridae, on the other hand, we only sampled the morphospecies Hister sp. 1, with a relative frequency of $0.9 \%$, represented in both season (Tab. 1 ).

When subjected to ANOVA, the data collected demonstrated that the rainy period presented a greater significance for richness ( $P$ $=0.0102)$ and the dry period a greater significance for abundance $(P$ $<0.0001)$. Regarding the environmental variables analyzed, a greater variation in temperature was noted between the two periods; however, the relative humidity of the air did not vary significantly (Fig. 2).

The greater abundance of beetles in the dry period is corroborated by Oliveira-Costa (2007) and can be explained by the fact that the high temperature accelerates the decomposition process, increasing the propagation of the characteristic odors of the decomposition, in addition to directly increasing the activity of the insects (Oliveira-Costa 2007). The collected Coleoptera are of great forensic importance, and Table 1. Abundance, absolute and relative frequency of Coleoptera collected with a Pitfall in the dry and rainy periods, in the Parque Metropolitano de Pituaçu, Salvador, Bahia.

\begin{tabular}{|c|c|c|c|c|c|c|}
\hline Family & Subfamily & Species/morphospecies & Dry Period & Rainy Period & Absolute Frequency & Relative Frequency (\%) \\
\hline \multirow[t]{3}{*}{ Staphylinidae } & Staphylininae & Xanthopygus bicolor & 2 & 0 & 2 & 0.9 \\
\hline & & Eulissus sp. 1 & 0 & 3 & 3 & 1.2 \\
\hline & Aleocharinae & Aleochara sp. 1 & 0 & 2 & 2 & 0.9 \\
\hline Histeridae & & Hister sp. 1 & 1 & 1 & 2 & 0.9 \\
\hline \multirow[t]{3}{*}{ Scarabaeidae } & Scarabaeinae & Ontherus sp. 1 & 3 & 2 & 5 & 2.0 \\
\hline & & Dichotomius sp. 1 & 172 & 53 & 225 & 94.1 \\
\hline & & Total & 178 & 61 & 239 & 100.0 \\
\hline
\end{tabular}

their capture in fauna studies in different regions of the country is common (Mise et al. 2007; Fonseca et al. 2020). These individuals act in different stages of the decomposition process and, therefore, can be used as an important tool in the determination of IPM, especially for cadavers found in an advanced state of decomposition (Lord \& Steverson 1986; Oliveira-Costa 2007).
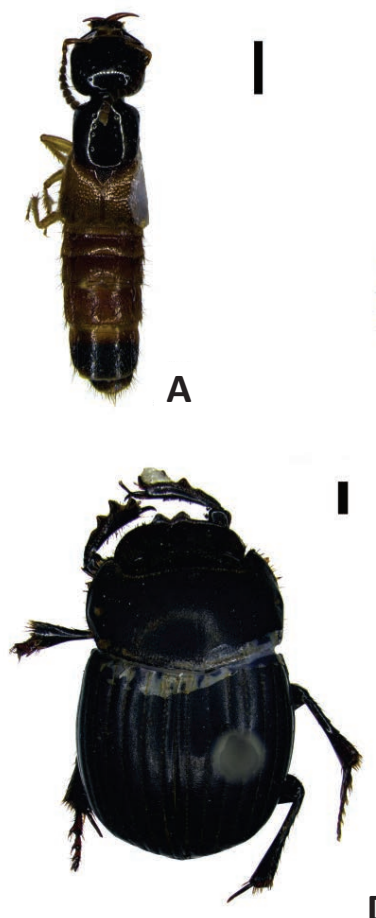

D

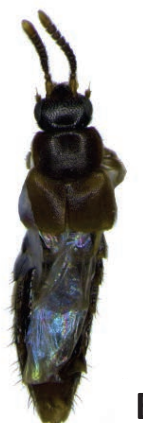

B

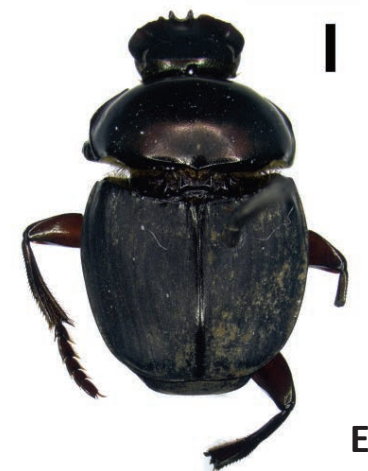

Figure 1. Species of Coleoptera collected, both photographed on dorsal view: (A) Xanthopygus bicolor Laporte, 1835; (B) Eulissus sp. 1; (C) Aleochara sp. 1; (D) Ontherus sp. 1; (E) Dichotomius sp. 1. Scale: $1 \mathrm{~mm}$.

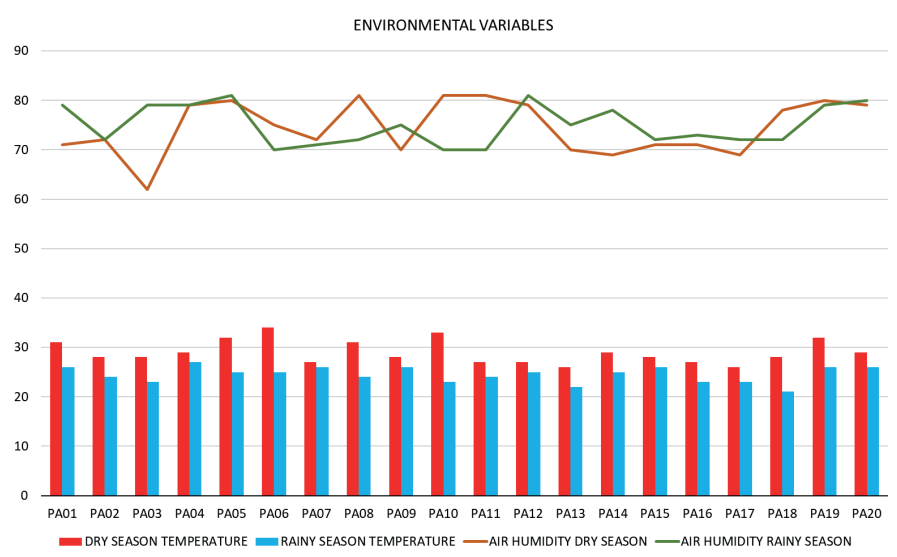

Figure 2. Average temperature (in ${ }^{\circ} \mathrm{C}$ ) and air humidity (in\%) measured at each Sample Point (PA) in the dry/rainy period.

Representatives of Scarabaeidae, in addition to their coprophagous habit, can be detritivores, scavengers, or herbivores both as larvae and as adults (Almeida \& Mise 2009; Silva et al. 2014). In general, they are

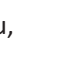


present in the dry phases of decomposition, populating the cadaverous micro-habitat in both the larval and adult forms (Oliveira-Costa 2007).

The main characteristic of Staphylinidae is their short elytron pair which enables a more efficient flight when compared to other individuals of the order. This is in agreement with Gnaspini et al. (2000), who captured the majority of their individuals in flight interception traps. Its presence is observed by Mise et al. (2010) in all stages of decomposition, generally acting as a predator of Diptera larvae, giving it extreme forensic importance.

The coleoptera of the family Histeridae are morphologically short and compact, with a very hard coat, and are usually generalist predators (Leivas et al. 2013). They are abundant in the decomposition process (Mise et al. 2007), and their abundance is directly related to their habit as a predator of Diptera larvae (Mise et al. 2007). Several researchers have already reported the presence of Histeridae at different stages of carcass decomposition (Mise et al. 2007; Fonseca et al. 2020).

The use of mixed bait (chicken gizzard and sardines) to capture insects of forensic interest has been suggested by other researchers, such as Mise et al. (2007), as it mainly attracts scavenger insects which act directly on cadaveric decomposition. All species/genera sampled in this study have already been considered of forensic importance in other studies (Mise et al. 2007; Almeida \& Mise 2009; Almeida et al. 2015), which was corroborated by the collection methodology adopted in the present studies. Finally, this study contributes to the knowledge of the entomofauna of forensic importance in an urban fragment of Salvador, helping to expand the knowledge of the distribution of relevant species in this field of studies.

\section{Acknowledgments}

We thank the Ministério do Meio Ambiente (MMA) and Instituto do Meio Ambiente e Recursos Hídricos (INEMA) in Bahia, for the collection licenses. Also to Romero Nazaré and Thiago Mahlmann for their assistance in the identification process.

\section{Authors' Contributions}

All authors contributed substantially to review the literature and writing the manuscript.

\section{References}

Almeida, L. M; Corrêa, R. C; Grossi, P. C. (2015) Coleoptera species of forensic importance from Brazil: an updated list. Revista Brasileira de Entomologia, 59(4): 274-284. doi: 10.1016/j.rbe.2015.07.008

Almeida, L. M.; Mise, K. M. (2009) Diagnosis and key of the main families and species of South American Coleoptera of forensic importance. Revista Brasileira de Entomologia, 53(2): 227-244. doi: 10.1590/S0085-56262009000200006

Amendt, J.; Krettek R.; Zehner, R. (2004) Forensic entomology. Naturwissenschaften, 91(2): 51-65. doi: 10.1007/s00114-0030493-5

Bahia (Estado) (2013) Secretaria de Desenvolvimento Urbano. Disponível em: http://www.sedur.ba.gov.br/governo-autorizaobras-de-revitalizacao-do-parque-de-pituacu/ Access on: 4.vi. 2013.

Borror, D. J.; DeLong, D. M. (2010) Introdução ao Estudo dos insetos. São Paulo: USP.

Catts, E. P.; Goff, M. L. (1992) Forensic entomology in criminal investigations. Annual Review of Entomology, 37: 253-272. doi: 10.1146/annurev.en.37.010192.001345

Fonseca, P. P. da; Thé, T. S.; Oliveira, F. F.; Pamponet, F. M.; Lopes, D. S. (2020) Estudo preliminar da comunidade de coleópteros de potencial forense, coletados em carcaça de suíno exposta em fragmento de Mata Atlântica no município de Salvador - Bahia. Revista Internacional de Ciências, 10(2): 85-98. doi: 10.12957/ ric. 2020.50002

Gnaspini, P.; Francini-Filho, R. B.; Burgierman, M. R. (2000) Abundance and seasonal activity of beetles (Coleoptera) in an Atlantic Forest Reservation in São Paulo City (Brazil). Revista Brasileira de Entomologia, 44(3/4): 115-127.
Kulshrestha, P.; Satpathy, D. K. (2001) Use of beetles in forensic entomology. Forensic Science International, 120(1-2): 15-17. doi: 10.1016/S0379-0738(01)00410-8

Leivas F. W. T; Grossi P. C; Almeida, L. M. (2013) Histerídeos (Staphyliniformia: Coleoptera: Histeridae) dos Campos Gerais, Paraná, Brasil. Biota Neotropica, 13(2): 196-204. doi: 10.1590/ S1676-06032013000200019

Lopes, D. S.; Oliveira, F. F. de; Mello-Patiu, C. A. de; Pamponet, F. M.; Thé, T. S. (2018) Espécies de Oxysarcodexia (Diptera: Sarcophagidae) associadas a carcaças de suínos (Sus scrofa Linnaeus) expostas em um fragmento de Mata Atlântica no município de Salvador, Bahia. EntomoBrasilis, 11(2): 103-106. doi: 10.12741/ebrasilis.v11i2.779

Lord, W. D.; Stevenson, J. R. (1986) Directory of forensic entomologists. 2 ed. Misc. Publ. Armed Forces Pest Mgt. Board, Washington, D.C.

Lima, D. C. de O.; Ramos, M. A.; Silva, H. C. H.; Alves, A. G. C. (2016) Rapid assessment of insect fauna based on local knowledge: comparing ecological and ethnobiological methods. Journal of Ethnobiology and Ethnomedicine, 12:15. doi: 10.1186/s13002-016-0085-z

Mise, K. M.; Almeida, L. M.; Moura, M. O. (2007) Levantamento da fauna de Coleoptera que habita a carcaça de Sus scrofa L., em Curitiba, Paraná. Revista Brasileira de entomologia, 51(3): 358-368. doi: 10.1590/S0085-56262007000300014

Mise, K. M.; Souza, A. S. B. de; Campos, C. M. (2010) Coleoptera associated with pig carcass exposed in a forest reserve, Manaus, Amazonas, Brazil. Biota Neotropical, 10(1): 321-324. doi: 10.1590/ S1676-06032010000100027

Mishra, G.; Srivastava, S.; Panda, B. K.; Mishra, H. N. (2017) Rapid Assessment of Quality Change and Insect Infestation in Stored Wheat Grain Using FT-NIR Spectroscopy and Chemometrics. Food Analytical Methods, 11: 1189-1198. doi: 10.1007/s12161-0171094-9

Oliveira-Costa, J. (2007) Entomologia forense: quando os insetos são vestígios. 2a Ed. Campinas, SP: Millennium Editora. (Tratado de perícias criminalísticas)

Oliveira, M. L.; Fernandes, D. R. R.; Alvarenga, T. M.; Andena S. R.; Araujo, R. O.; Azevedo, C. O.; Barbosa, D. N.; Bartholomay, P. R.; Costa, V. A.; DalMolin, A., et al. (2021) Hymenoptera. In: Catálogo Taxonômico da Fauna do Brasil. PNUD. http://fauna.jbrj.gov.br/ fauna/faunadobrasil/96. Access on: 1.vi.2021

Pamponet, F.; Lopes, D.; Véras, T.; Fonseca, P.; Vasconcelos, S.; Torres, M.; Grisi, B.; Oliveira, F.; Thé, T.; Oliveira-Costa, J. (2019) Análise temporal de Calliphoridae (Diptera: Cyclorrhapha) no processo de decomposição em carcaças de suínos (Sus scrofa Linnaeus) em Salvador, Bahia, Brasil. EntomoBrasilis, 12(2): 63-69. doi: 10.12741/ ebrasilis.v12i2.846

Pujol-Luz, J. R.; Arantes, L. C.; Constantino, R. (2008) Cem anos da Entomologia Forense no Brasil (1908-2008). Revista Brasileira de Entomologia, 52(4): 485-492. doi: 10.1590/s008556262008000400001

Rafael, J. A.; Melo, G. A. R.; Carvalho, C. J. B.; Casari, S. A.; Constantino, R. (2012) Insetos do Brasil: Diversidade e Taxonomia. 1a Ed. Ribeirão Preto: Holos.

Ramos, R. L; Lopes, D. S; Pamponet, F. M; Thé, T. S; Morato, V. C. G. (2018) Primeiro registro de Peckia (Squamatodes) trivittata (Curran) (Diptera: Sarcophagidae) colonizando cadáver humano carbonizado em área de restinga da Bahia, Brasil. EntomoBrasilis, 11(2): 151-153. doi: 10.12741/ebrasilis.v11i2.765

Silva, P. S.; Vaz-de-Mello, F. Z.; Di Mare, R. A. (2011) Guia de identificação das espécies de Scarabaeinae (Coleoptera: Scarabaeidae) do município de Santa Maria, Rio Grande do Sul, Brasil. Biota Neotropical, 11(4): 329-345. doi: 10.1590/S167606032011000400027

Silva, R. J.; Coletti, F.; Costa, D. A.; Vaz-De-Mello, F. Z. (2014). Rolabostas (Coleoptera: Scarabaeidae: Scarabaeinae) de florestas e pastagens no sudoeste da Amazônia brasileira: Levantamento de espécies e guildas alimentares. Acta amazônica, 44(3): 345-352. doi: 10.1590/1809-4392201304472 